\title{
УГРОЗА РОСТА НАСИЛИЯ В СЕВЕРНОЙ ИРЛАНДИИ В КОНТЕКСТЕ БРЕКЗИТА
}

Аннотация. В статье рассматривается возрастание нестабильности в Северной Ирландии и возможное обострение насильственного противостояния республиканцев и юнионистов в регионе, обусловленное выходом Соединённого Королевства из Европейского союза. На основании официальных документов Европейского союза, исследований Европола $u$ ЮНЕСКО автор выявляет потенциальные угрозы мирному процессу в Северной Ирландии. Эти угрозы во многом связаны с риском восстановления физической границы на острове Ирландия и актуализацией идеи объединения двух частей острова. В статье также изучается роль Европейского союза в процессе мирного урегулирования в Северной Ирландии и в вопросе обустройства ирландской границы после выхода Великобритании из ЕС.

Ключевые слова: брекзит, Северная Ирландия, Республика Ирландия, Европейский союз, Соединённое Королевство, ирландская граница, соглашение Страстной пятнищь, ИРА, насилие.

19 января 2019 г. в печально известном североирландском городе Дерри, который британцы называют Лондондерри, произошёл теракт: взорвался припаркованный на улице автомобиль. Чудом не пострадали люди, но был нанесён значительный ущерб окружающим зданиям. Камеры наружного наблюдения засняли двоих молодых людей, оставивших заминированную машину на улице. 5 марта 2019 г. были обнаружены пять посылок с взрывными устройствами в Лондоне, Глазго и ирландском городе Лимерик. Британская разведка МИ-5 предположила, что за этими действия стоит диссидентская террористическая группировка Новая Ирландская республиканская армия, которая сама себя именует Ирландской республиканской армией (ИРА). Таким образом, над регионом навис призрак, казалось, ушедшего в прошлое насилия. Во многом активизация террористической деятельности спровоцирована грядущим выходом Соединённого Королевства из Европейского союза и возможным восстановлением границы на острове Ирландия.

\section{Мирный процесс в Северной Ирландии}

Насилие, длившееся в Северной Ирландии более 30 лет, было остановлено в 1998 г. с подписанием Белфастского соглашения ${ }^{1}$, известного также как соглашение Страстной пятницы. Основной идеей масштабного документа стало предоставление возможности всем заинтересованным сторонам участвовать в переговорах и таким образом достичь взаимного согласия². По соглашению Страстной пятницы предполагалось создать Североирландскую Ассамблею, Министерский межирландский совет Север-Юг и британо-ирландский совет, вне-

(C) Бабынина Людмила Олеговна - кандидат политических наук, ведущий научный сотрудник, руководитель Центра политической интеграции Отдела исследований европейской интеграции ИЕ РАН. Adpec: 125009, Россия, Москва, ул. Моховая, д. 11, стр. 3; доцент факультета мировой политики МГУ им. М.В. Ломоносова. E-mail: lbabynina@yandex.ru.

DOI: http://dx.doi.org/10.15211/vestnikieran220193337

${ }^{1}$ The Belfast Agreement. 10 April 1998. URL: https://cain.ulster.ac.uk/events/peace/docs/agreement.pdf.

2 Еремина Н.В. Деволюция в кельтских регионах Соединённого Королевства как модель государственного развития. Спб.: СПбГУ, 2011. Стр. 171. 
сти поправки в конституцию Республики Ирландия для отказа от территориальных претензий на Северную Ирландию, разоружить разнообразные военизированные группировки в Северной Ирландии, реформировать полицию Ольстера. Документ подписали премьер-министр Великобритании Тони Блэр и премьер-министр Республики Ирландия Берти Ахерн. Практически все политические силы региона, в том числе и политическое крыло ИРА - партия Шинн Фейн, запрещённая ранее, выступили за соглашение. Против была только крайне правая Демократическая юнионистская партия (ДЮП) Северной Ирландии. Часть лидеров и рядовых членов ИРА, не согласившихся сложить оружие, откололись от основной группировки и создали новою организацию Реальную (Новую) ИРА (RIRA) ${ }^{1}$. В подготовке и последующей реализации соглашения активно принимал участие Европейский союз и США.

Реализация соглашения шла непросто. Она сопровождалась рядом парламентских кризисов, несколько раз вводилось прямое управление из Лондона. В 2000 г. Независимая международная комиссия по наблюдению (IMC) заявила о невыполнении ИРА плана по разоружению. Новая ИРА (RIRA) не прекращала террористических действий, которые были направлены против вновь созданной Полицейской службы Северной Ирландии и частей британской армии, расположенных в регионе. Однако уличное насилие постепенно прекратилось. В 1997 г. Ирландская республиканская армия объявила о прекращении огня, а в 2005 г. - о полном разоружении, что позже неоднократно подтверждалось международной комиссией.

Претворению соглашения в жизнь во многом способствовал тот факт, что Соединённое Королевство и Республика Ирландия входили в Единый внутренний рынок (ЕВР) и Таможенный союз (ТС) Европейского союза, что предполагает отсутствие таможенного контроля на границе и свободу передвижение факторов производства. Кроме того, Республика Ирландия и Соединённое Королевство объединены Общей зоной передвижения (Common Travel Area СТА), которая в настоящее время гарантирует равные права резидентам обеих стран. После подписания соглашения Страстной пятницы 17 укреплённых блокпостов на ирландской границе были ликвидированы. С учётом правил функционирования ЕВР и ТС и отсутствием паспортного контроля в рамках СТА, граница стала прозрачной.

Прекращение насилия в Северной Ирландии и прозрачность границы способствовали тому, что стал активно развиваться трансграничный бизнес на острове, а также хозяйственные и культурные связи. Значительный вклад в поддержание мира и развитие регионов вносит Европейский союз. Средства на эти цели поступают через специально созданную для мирного урегулирования программу PEACE, программу INTERREG, направленную на социально-экономическое и территориальное сплочения регионов Республики Ирландии, Северной Ирландии и Западной Шотландии, а также в рамках сельскохозяйственной политики ЕС. Молодёжь обеих частей острова активно использует возможности обучения в рамках программы Эразмyс + .

\section{Брекзит как угроза мирному процессу}

Неожиданная угроза мирному процессу возникла в связи с результатами референдума о членстве Соединённого Королевства в Евросоюзе и его намерением покинуть объединение. Необходимо отметить, что если в целом по стране за выход из Евросоюза проголосовали 51,9\% населения, то в Северной Ирландии $55,8 \%$ выступили за сохранение членства в ЕС ${ }^{2}$. Причём за выход голосовали преимущественно протестантские районы Ольстера с английским и шотландским населением, а против - ирландские районы. Очевидно, что ирландцы не поддержи-

\footnotetext{
${ }^{1}$ Новой ИРА группировку назвали журналисты. Сами члены RIRA называет себя просто ИРА.

${ }^{2}$ BBC.com. URL: https://www.bbc.com/news/politics/eu_referendum/results.
} 
вают идею нового разделения острова. Опасности для мирного процесса могут быть различными.

Во-первых, в случае выхода Соединённого Королевства из Единого внутреннего рынка и Таможенного союза ЕС на острове Ирландия появится физическая граница, на которой будет осуществляться таможенный, а возможно и паспортный контроль ${ }^{1}$. Наличие пропускных пунктов не только усложнит повседневную жизнь приграничных регионов, работу бизнеса и передвижение людей, но будет нести и негативный психологический эффект, отсылая к временам насилия и «Смуты» (Troubles).

Во-вторых, ирландские националисты рассматривают брекзит как «огромную помощь» и уникальную возможность для объединения острова ${ }^{2}$. Практически сразу после референдума был актуализирован вопрос об объединении двух Ирландий. Об этом заявила партия Шинн Фейн, которая действует по обе стороны границы и которая никогда не убирала пункт об объединении Ирландии из своих программ. В некотором смысле масла в огонь подлил и Европейский союз. Формулируя основные принципы и цели переговоров о выходе Великобритании, ЕС отметил, что в случае демократически принятого решения о воссоединении Республики Ирландия с Северной Ирландией последняя сможет войти в состав Союза по аналогии с ГДР ${ }^{3}$. До проведения референдума 2016 г. за объединение Ирландии выступали немногим более $20 \%$ населения Ольстера. Однако брекзит и восстановление границы может сильно изменить ситуацию.

Кроме того, за последние десятилетия изменилась демографическая ситуация в Северной Ирландии. Если ещё в середине XX в. протестанты, выходцы из Англии и Шотландии, составляли большинство, то в настоящее время в регионе небольшой перевес имеет ирландское население, значительную часть которого составляет молодёжь до 25 лет, которая не жила в условиях разделенного острова и перманентного насилия.

В-третьих, в Северной Ирландии диссидентские группы активизировали свою террористическую деятельность и стали активнее проводить агитацию, в первую очередь, среди молодёжи. По данным Европола ${ }^{4}$, за 2018 г. было совершено 88 попыток нападений, взрывов и других террористических действий на территории Северной Ирландии. В основном они были направлены против полиции Ольстера и британской армии. За бо́льшую часть нападений ответственность взяла Новая ИРА, которая никогда не признавала соглашение Страстной пятницы и практически не прекращала террористической деятельности. Группировка выступает за объединение Ирландии, но признаёт только насильственные методы, полагая, что рост насилия заставит власти согласиться на проведение референдума. В отчёте также отмечается, что Новая ИРА имеет активные связи с криминальными структурами, в том числе, связанными с распространением наркотиков. Наблюдатели ЮНЕСКО отмечают ${ }^{5}$ определённый рост радикализации среди молодёжи, в первую очередь ирландской. Следует отметить, что Шинн

\footnotetext{
${ }^{1}$ Паспортный контроль может быть введён Великобританией для граждан ЕС, прибывающих в Республику Ирландия из других стран Евросоюза. Чтобы избежать проверок на сухопутной ирландской границе Британия осенью 2016 г. даже предлагала ирландской стороне допустить свои иммиграционные службы в по́рты и аэропорты Ирландии, что не нашло, однако, поддержки у ирландских политиков.

${ }^{2}$ The Guardian. Brexit is a «huge help» to Irish republicanism, says dissident leader. URL: https://www.theguardian. com/world/2019/mar/06/brexit-is-a-huge-help-to-irish-republicanism-says-dissident-leader.

${ }^{3}$ European Council (Art. 50) guidelines following the United Kingdom's notification under Article 50 TEU. URL: http://www.consilium.europa.eu/en/press/press-releases/2017/04/29-euco-brexit-guidelines/

${ }^{4}$ Europol. EU Terrorism Situation and Trend Report 2018. P. 45. URL: https://www.europol.europa.eu/activitiesservices/main-reports/european-union-terrorism-situation-and-trend-report-2018-tesat-2018.

${ }_{5}$ UNESCO. Northern Ireland Returning to Violence as a Result of a Hard Border due to Brexit or a Rushed Border Poll: Risks for Youth. P. 8-10, 50. URL: https://senatormarkdaly.files.wordpress.com/2019/02/unesco-chairs-reportbrexit-return-to-violence.pdf.
}

Научно-аналитический вестник ИЕ РАН, 2019, №2 
Фейн и бывшие лидеры ИРА осуждают террористическую активность Новой ИРА и других диссидентских групп.

В настоящее время именно вопрос границы на острове Ирландия стал основным камнем преткновения в процессе выхода Соединённого Королевства из ЕС. Евросоюз и Великобритания подчёркивают, что не хотят возвращения физической границы на острове Ирландия, однако практическое решение данной проблемы пока не найдено. В проекте соглашения о выходе Соединённого Королевства из $\mathrm{EC}^{1}$ прописано, что стороны создадут единую таможенную территорию. Таким образом, страна полностью остаётся в Таможенном союзе с ЕС на не определённое чётко время. При этом таможенные правила в Северной Ирландии будут в большей степени коррелироваться с правилами ЕС, отличаясь от остальных частей страны на острове Великобритания.

Если же не будет найдено «уникальное решение» для ирландской границы, то в силу вступит страховочное решение (backstop solution), которое фактически оставит Северную Ирландию в правом поле ЕВР и Таможенного союза ЕС. Против этих положений выступили сторонники жёсткого брекзита из партии консерваторов и ДЮП, что привело к провалу ратификации соглашения. Сохранение границы прозрачной позволило бы предотвратить радикализацию части общества, снизило бы растущую напряжённость в регионе. К сожалению, эта проблема не рассматривается сторонниками жёсткого брекзита в Консервативной партии и ирландскими юнионистами как приоритетная. ЕC, со своей стороны, уже заявил, что вне зависимости от исхода ратификации соглашения, сохранит действие программ PEACE, INTERREG и Эразмус+ до конца 2020 г.

\section{Выводы}

Сохранение неопределённости в вопросе выхода Великобритании из ЕС не добавляет стабильности Северной Ирландии, где две ведущие партии, ирландская Шинн Фейн и Демократическая юнионистская партия Северной Ирландии, долгое время не могут преодолеть разногласия и сформировать региональное правительство. В отношении брекзита они также занимают противоположные позиции. Возможный выход Британии «без сделки» означает автоматическое восстановление границы и таможенного контроля, рост цен, разрыв хозяйственных связей и, как следствие, актуализацию идеи объединения острова, а следовательно, потенциальный рост насилия со стороны диссидентских группировок для достижения этой цели.

Ситуация, сложившаяся вокруг ирландской границы и потенциального роста нестабильности в Северной Ирландии, подтверждает очевидный факт, что процессы региональной интеграции ведут к установлению более тесных хозяйственных и человеческих связей, а в итоге к укреплению мира в нестабильных регионах. Особенно очевидно это становится при наличии функционального перелива из экономики в политику. Разрыв интеграционных связей ведёт к общей дестабилизации, что особенно опасно для регионов, где существует традиции применения насилия.

\section{Литература}

Еремина Н.В. Деволюция в кельтских регионах Соединённого Королевства как модель государственного развития. Спб.: СПбГУ, 2011.

Охошин О.В. Брекзит может снова «остановиться» на североирландской границе. Инсти-

\footnotetext{
${ }^{1}$ Agreement on the withdrawal of the United Kingdom of Great Britain and Northern Ireland from the European Union and the European Atomic Energy Community. URL: https://www.consilium.europa.eu/media/37099/ draft_withdraw al_agreement_incl_art132.pdf.
}

Научно-аналитический вестник ИЕ РАН, 2019, №2 
тут Европы РАН. Аналитическая записка №41(137), 2018. URL: http://instituteofeurope.ru/ images/uploads/analitika/2018/an137.pdf.

Полякова Е.Ю. Ирландия в ХХ веке: учебное пособие. М.: КДУ, 2009.

\section{References}

Agreement on the withdrawal of the United Kingdom of Great Britain and Northern Ireland from the European Union and the European Atomic Energy Community. URL: https://www.consilium.europa.eu/media/37099/draft_withdrawal_agreement_incl_art132.pdf.

Council of the European Union. Annex to the Council Decision. Brussels, 29 January 2018. URL: http://www.consilium.europa.eu//media/32504/xt21004-ad01re02en18.pdf.

European Council (Art. 50) (23 March 2018) - Guidelines. URL: http://www.consilium.europa. eu/media/33458/23-euco-art50-guidelines.pdf.

Eremina N.V. Devolyuciya v kel'tskih regionah Soedinennogo Korolevstva kak model' gosudarstvennogo razvitiya. Spb.: SPbGU, 2011.

European Council (Art. 50) guidelines following the United Kingdom's notification under Article 50 TEU. URL: http://www.consilium.europa.eu/en/press/press-releases/2017/04/29-euco-brexitguidelines/

Europol. EU Terrorism Situation and Trend Report 2018. URL: https://www.europol.europa.eu/ activities-services/main-reports/european-union-terrorism-situation-and-trend-report-2018-tesat-2018.

Ohoshin O.V. Brekzit mozhet snova «ostanovit'sya» na severoirlandskoj granice. Institut Evropy RAN. Analiticheskaya zapiska №41(137), 2018. URL: http://instituteofeurope.ru/images/ uploads/analitika/2018/an137.pdf.

Polyakova E.YU. Irlandiya v XX veke: uchebnoe posobie. M.: KDU, 2009.

The Belfast Agreement. 10 April 1998. URL: https://cain.ulster.ac.uk/events/peace/docs/ agreement.pdf.

UNESCO. Northern Ireland Returning to Violence as a Result of a Hard Border due to Brexit or a Rushed Border Poll: Risks for Youth. P. 8-10, 50. URL: https://senatormarkdaly.files.wordpress. com/2019/02/unesco-chairs-report-brexit-return-to-violence.pdf.

\section{The Threat of Increased Violence in the Northern Ireland in the Context of Brexit}

Author. Liudmila Babynina, Candidate of Sciences (Politics), Head of the Center for Political Integration studies, Institute of Europe RAS. Address: 11-3, Mokhovaya str., Moscow, Russia, 125009; Associate Professor, Faculty of the World Politics, Lomonosov Moscow State University. E-mail: lbabynina@yandex.ru.

Abstract. The paper considers the increasing instability in Northern Ireland and the possible aggravation of violent confrontation between Republicans and Unionists in the region due to the withdrawal of the United Kingdom from the European Union. On the basis of official documents of the European Union, Europol and UNESCO, the author identifies potential threats to the peace process in Northern Ireland. Threats are largely associated with the risk of restoring the physical border on the island of Ireland and the actualization of the idea of unification two parts of the island. The paper also discusses the role of the European Union in the process of peaceful settlement in the Northern Ireland and in the management of the Irish border after Brexit.

Key words: Brexit, Northern Ireland, Republic of Ireland, European Union, United Kingdom, Irish Border, Good Friday Agreement, IRA, violence.

DOI: http://dx.doi.org/10.15211/vestnikieran220193337

Научно-аналитический вестник ИЕ РАН, 2019, №2 